\title{
A Study on Problem Solving Ability of Government Secondary School Students in Aizawl City with Reference to Gender
}

\author{
M.S. Dawngliani, Lalruatfeli Ralte and Lallianzuali Fanai* \\ IGNOU Centre, Institute of Advanced Studies in Education, Republic Veng, Aizawl Mizoram, WB. India \\ *Corresponding author: dr.zuali@gmail.com
}

Received: 22 June, 2019

Revised: 28 Sept., 2019

Accepted: 19 Nov., 2019

\begin{abstract}
The aim of this research is to study the problem-solving ability among Government secondary school students in Aizawl city. For this purpose, the sample was selected from different secondary school within Aizawl City. The sample consisted of 90 students. Out of 46 students male students and 44 female students were taken. Problem Solving Ability Test (PSAT) developed by L.N. Dubey was used as a tool for data collection. Mean and t-test were used to analysed the data. The findings of the study reveal that no significant difference was found in relation to gender and there is high ability of problem-solving ability of Government secondary school students.
\end{abstract}

Keywords: Problem solving ability, Government school, gender.

Problem solving ability here means to test the students' ability to learn or understand a new and difficult situation. It also includes the skills of the students, the level of students' ability to apply knowledge to manipulate one's environment while also to think abstractly as measured by objective criteria. In our daily life, we face many problems, it may be different types on the basis of our life styles, and we try to solve those problems as far as possible on our own. The right way to solve the problem can be done by only right thinking and proper reasoning which depends upon the level of intelligence of individual. According to Woodsworth and Marquis (1948) "Problem Solving behaviour occurs in novel or difficult situations in which a solution is not obtainable by the habitual methods of applying concepts and principles derived from past experience in very similar situation."

In India, each state has its own Department of
Education that runs its own school system with its own textbooks and evaluation system. The curriculum, pedagogy and evaluation method are largely decided by the SCERT in the state, following the national guidelines prescribed by the NCERT. Each state has three kinds of schools that follow the state curriculum. The government runs its own schools in land and buildings owned by the government and paying the staff from its own resources. These are generally known as government schools. The fees are quite low in such schools. Then there are privately owned schools with their own land and buildings. Here the fees are high and the teachers are paid by the management. Such

\footnotetext{
How to cite this article: Dawngliani, M.S., Ralte, L. and Fanai, L. (2019). A Study on Problem Solving Ability of Government Secondary School Students in Aizawl City with Reference to Gender. Int. J. Peace, Edu. and Deve., 7(02): 115-119.

Source of Support: None; Conflict of Interest: None
} 
schools mostly cater to the urban middle-class families. The third kind consists of schools that are provided grant-in-aid by the government, though the school was started by a private agency in their own land and buildings. The grant-in-aid is meant to help reduce the fees and make it possible for poor families to send their children.

\section{Rationale of the Study}

Aizawl city is the state capital of Mizoram. In Mizoram there are three kind of secondary schools i.e. Government schools, Grand-in-Aided and private schools. In Government schools, all the infrastructure and facilities are provided by the government. According to RMSA policy, school should be inclusive school. That means children those who are between 14-16 years should be admitted in the appropriate class. From the abovementioned nature of government school shows that the students in government school at the secondary level in Mizoram are diverse in their learning behaviour. The present study tries to find out what ability in problem solving among government secondary school students in Aizawl city. Also, the ability of problem solving in relation to gender and comparison between male and female students in the government secondary school is needed for further improvement of government school. The research study on problem solving ability of government secondary school students may also be fruitful for the teacher in the teaching of mathematics subject. Problem solving ability is highly a cognitive process, so the finding of the study can tell us the nature of students precisely. The investigator felt that the importance to study on that areas.

\section{Objectives of the study}

1. To find out the level of Problem-solving ability of Governments' secondary school students in Aizawl City.

2. To find out the level of Problem-solving ability of male students of Governments' secondary school of in Aizawl City.

3. To find out the level of Problem-solving ability of female students of Governments' secondary school in Aizawl City.
4. To compare problem solving ability of Government secondary school students in relation to gender.

\section{Hypotheses of the study}

There is no significant difference between problemsolving ability of male and female students of Government secondary school students in Aizawl city.

\section{Research Design}

The investigator adopted descriptive survey approach for the present study as it surveys and inquire problem solving ability of secondary school students.

\section{Population and Sample}

The population of the present study comprise of all the class 9 students in Government secondary school in Aizawl city. The investigator selected 6 Government secondary school.

\section{Tools used}

The investigator used consumable booklet of PSAT-d (English version) design by L.N. Dubey published by National Psychological Corporation, Agra.

Reliability: the reliability coefficient of the test was calculated by two methods in which .78 was the reliability coefficient in Spearman-Brown formula (split-half method) while .76 was Kudar-Richardson formula (Rational equivalent method).

Validity: The coefficient of validity was calculated by correlation the scores were .68 and .85 in Group Intelligence test (R.K. Tandon) and Test of Reasoning Ability respectively

\section{Data Collection}

The investigator randomly selected different Secondary school in Aizawl city and visited them to ask for the permission of the Principal to administer the tool on the selected sample students of class IX. After getting permission, the investigator had made a good rapport, and administered the test on the students. The test scored were collected and entered as a raw score for further analysis. 


\section{Data analysis}

Statistical analysis through t-test was used to test the hypothesis. Percentage and mean were adopted to find out the level of problem-solving ability of the students.

\section{Analysis and interpretation}

Analysis and interpretation are done in accordance with the objectives of the study as follows:

1. To investigate the level of Problem-solving ability of government secondary school students in Aizawl City.

In order to find out the level of problem-solving ability of secondary school students in Aizawl city the scores obtained from the scale are analysed and interpreted in accordance with the norms provided in the manual of the scale and the finding are presented in the following table:

Table 1: Level of Problem-solving ability of Government secondary school students

\begin{tabular}{cccc}
\hline S1. No & Level of PSAT & No. of students & Percentage \\
\hline 1 & Very High & 41 & 46 \\
2 & High Ability & 22 & 24 \\
3 & Average Ability & 16 & 18 \\
4 & Low Ability & 6 & 7 \\
5 & Very low Ability & 5 & 5 \\
\hline
\end{tabular}

Analysis of the above table 1 shows that $46 \%$ of the students have very high problem-solving ability while $24 \%$ have High Ability of problem-solving ability whereas $18 \%$ of the students have Average Ability of problem-solving ability while $7 \%$ of the students have low ability and $6 \%$ of the students have Very low ability of problem-solving ability.

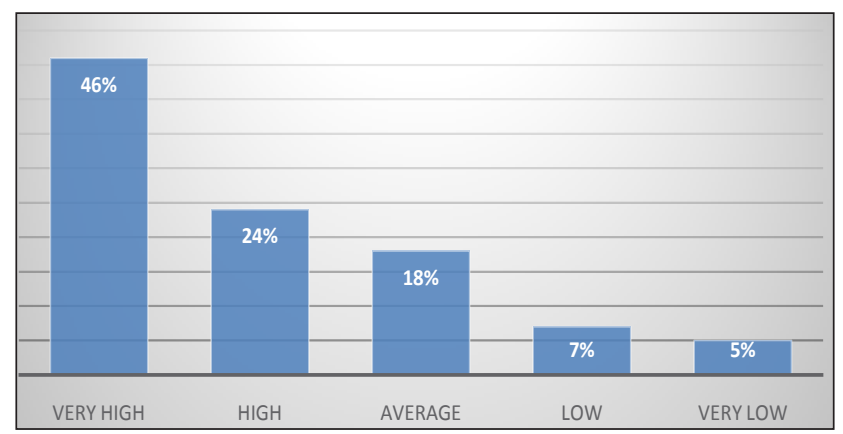

Fig. 1: Percentage Scores of problem-solving Ability of government secondary school students in Aizawl City
2. To investigate the level of Problem-solving ability of government secondary school Male students in Aizawl City.

In order to find out the level of problem-solving ability of government secondary school Male students in Aizawl city the scores obtained from the scale are analysed and interpreted in accordance with the norms provided in the manual of the scale and the finding are presented in the following table:

Table 2: Level of Problem-solving ability of government secondary school Male students in Aizawl City

\begin{tabular}{cccc}
\hline $\begin{array}{c}\text { Sl. } \\
\text { No }\end{array}$ & Level of PSAT & $\begin{array}{c}\text { No. of } \\
\text { students }\end{array}$ & Percentage \\
\hline 1 & Very High & 20 & 45.45 \\
2 & High Ability & 12 & 27.27 \\
3 & Average Ability & 9 & 20.45 \\
4 & Low Ability & 3 & 6.82 \\
5 & Very low Ability & 2 & 4.54 \\
\hline
\end{tabular}

Analysis of the above table 2 shows that $45.45 \%$ of the students have very high problem-solving ability while $27.27 \%$ have High Ability of problem-solving ability whereas $20.45 \%$ of the students have Average Ability of problem-solving ability while 6.82 percent of the students have low ability and $4.54 \%$ of the students have Very low ability of problem-solving ability.

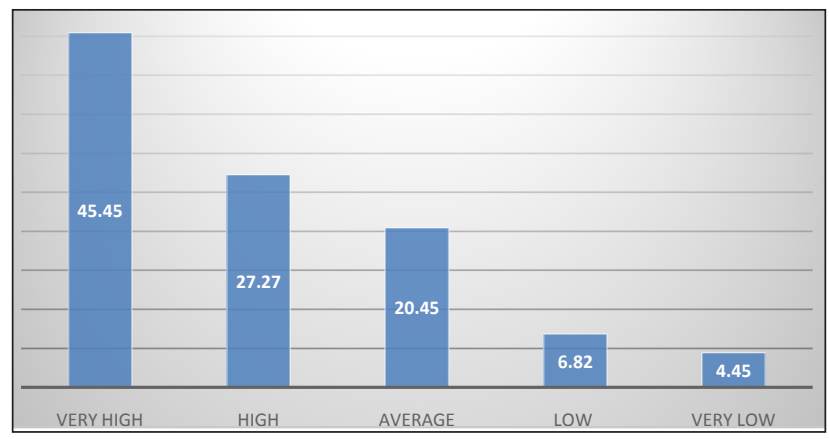

Fig. 2: Percentage Scores of problem-solving Ability of government secondary school Male students in Aizawl City

3. To investigate the level of Problem-solving ability of government secondary school female students in Aizawl City.

In order to find out the level of problem-solving 
ability of secondary school students in Aizawl city the scores obtained from the scale are analysed and interpreted in accordance with the norms provided in the manual of the scale and the finding are presented in the following table:

Table 3: Level of Problem-solving ability of government secondary school female students in Aizawl City

\begin{tabular}{cccc}
\hline $\begin{array}{c}\text { S1. } \\
\text { No }\end{array}$ & Level of PSAT & $\begin{array}{c}\text { No. of } \\
\text { students }\end{array}$ & Percentage \\
\hline 1 & Very High & 21 & 47.73 \\
2 & High Ability & 10 & 22.72 \\
3 & Average Ability & 7 & 15.91 \\
4 & Low Ability & 3 & 6.82 \\
5 & Very low Ability & 3 & 6.82 \\
\hline
\end{tabular}

Analysis of the above table 3 shows that $46 \%$ of the students have very high problem-solving ability while $24 \%$ have High Ability of problem-solving ability whereas $18 \%$ of the students have Average Ability of problem-solving ability while $7 \%$ of the students have low ability and $6 \%$ of the students have Very low ability of problem-solving ability.

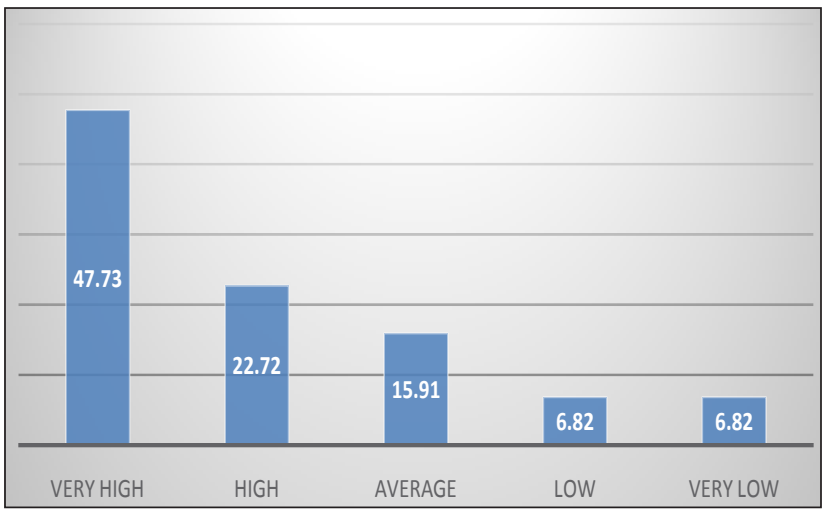

Fig. 3: Percentage Scores of problem-solving Ability of government secondary school Female the Students

4. To compare problem solving ability of government secondary school students in relation to Gender

The difference in the level of teaching interest between male and female students was compared. For this mean was calculated and the mean differences were tested by applying ' $t$ ' test and the detailed are presented in the following table 4 .
Table 4: Comparison of problem-solving Ability of Male and Female Students

\begin{tabular}{cccccc}
\hline $\begin{array}{c}\text { Problem-solving } \\
\text { ability }\end{array}$ & $\mathbf{N}$ & Mean & t-value & $\begin{array}{c}\text { Level of } \\
\text { significant }\end{array}$ \\
\cline { 1 - 2 } Male & 46 & 14.83 & \multirow{2}{*}{1.45} & N.S \\
\cline { 1 - 2 } Female & 44 & 13.91 & &
\end{tabular}

Analysis of data vide table 4 reflect the result for the test of significant differences between male and female students of secondary schools in relation to their level of problem-solving ability. The mean value for male and female students is 14.83 and 13.91 respectively. The table also reveals the $t$-value for the mean scores of male and female students towards problem-solving ability level found to be 1.45 which is not significant.

Therefore, the null hypothesis no.1, there is no significant differences in the level of problemsolving ability between male and female students of secondary schools is retained. This finding implies that problem-solving ability level of male and female students are not significantly different. Male and female students are not differed significantly in their ability of problem-solving.

\section{Major findings}

$\odot$ Average score on problem solving ability test of government secondary school students in Aizawl is 14.38 which is lie on the High-level ability according to the interpretation given by L.N. Dubey. Meanwhile Most of the students were under the level of very high ability of problem-solving ability. 63 out of 90 number of students, that is $70 \%$ lie on above average. Therefore, students of secondary school in Aizawl City were good in problem-solving ability.

$\odot$ Average score on problem solving ability test male students is 14.83 which is lie on the Highlevel ability according to the interpretation of boys given by L.N. Dubey. Meanwhile Most of the students were under the level of very high ability of problem-solving ability. 32 out of 46 number of students, that is $78.26 \%$ lie on above average. Therefore, students of 
secondary school in Aizawl City were good in problem-solving ability

$\odot$ Average score on problem solving ability test is 13.91 which is lie on the High-level ability according to the interpretation of Girls score given by L.N. Dubey. Meanwhile Most of the students were under the level of very high ability of problem-solving ability. 32 out of 44 number of students, that is $70.45 \%$ lie on above average. Therefore, students of secondary school in Aizawl City were good in problemsolving ability

$\odot$ In respect to gender, there is no difference in the level of problem-solving ability between male and female students of government secondary schools of Aizawl City.

\section{DISCUSSION}

The study reveal that the level of problem-solving ability is high among Government secondary school students in Aizawl city. There can be many reasons and factors which influence this result. This could be because of learning mathematics as compulsory subject. Problem-solving ability test is closely related with mathematics subject. It is a task finding of numerical problem involving highly thinking skill. Besides that, Mizoram Board of School Education (MBSE) introduces Higher Order Thinking Skills (HOTS) question in the question design at the level of secondary school. Teachers try to impart to activate higher order thinking ability among the students that may be helpful to raise the level of problem-solving ability of the secondary level students.

Gender wise analysis of the results reveals that there is no significant difference between male and female students in problem-solving ability. Similar result is found in the study of (Kumari, 2016) on problem-solving ability of Senior Secondary School Students. The supporter of the result is also found on the study of (Singh \& Gopalkhrishnan, 2017) effect of Gender on problem-solving Skills through Integrated Teaching Program. The same result had found by (Behra, 2009) on his study on problem- solving skills in mathematics learning. Manohra and Ramganesh (2009) conducted a study on creative problem-solving ability of 11th class students and find that the boys tend to excel girl in their creative problem-solving ability which contradict the result of the present study.

\section{CONCLUSION}

In the light of the findings presented in the above, the following conclusions are drawn. There is a satisfactory result in the Problem-solving ability test among secondary school students. So, the researcher felt that a study on Problem-solving ability of private school in the same city or other city can be taken up, how the student's ability in problem solving can affect their academic achievement? Is there any relation between the two areas? There is no significant difference between boys and girls in their Problem-solving ability. So that, the educational planner or administrator can be framed same policies for male and female students in secondary stage.

\section{REFERENCES}

Behra, B. 2009. problem-solving skills in mathematics learning. Edutracks, 8(7): 34.

Dubey, L.N. 2015. Manual for problem-solving Ability Test- ${ }_{D}$ (English Version). Agra, India: National Psychological Corporation.

Kumari, J. 2016. A study on problem-solving ability of senior secondary school students. Edutracks, 15(7): 21-23.

Mangal, S.K. 2010. Advanced educational psychology. ( $2^{\text {nd }}$ ed.). Delhi, India: PHI learning.

Manohara, J.L. and Ramganesh, E. 2009. Creative problemsolving ability of standard XI students, Edutracks, 9(4), 29-31.

Singh, P. and Gopalkhrishnan, V.S. 2017. Effect of gender on problem-solving skills through integrated teaching program. Edutracks, 17: 37-40.

Woodworth, J. \& Marquis, P. 1948. Psychology of Adults. In S.K.Mangal (Ed.) Advanced educational psychology (pp. 121-125). Delhi: PHI.

Kumar, V.S. 2011. The education system. Retrieved from https:// www.gnu.org/education/edu-system-india.en.html 
